\title{
Changes in haemostasis during normal pregnancy: does homocysteine play a role in maintaining homeostasis?
}

\author{
Valerie A. Holmes \\ Northern Ireland Centre for Diet and Health (NICHE), University of Ulster, Coleraine BT52 1SA, UK and Haematology \\ Department, Belfast City Hospital, Belfast BT9 7AB, UK
}

\begin{abstract}
Homocysteine, derived from the demethylation of the amino acid methionine, is either further catabolised by trans-sulfuration to cysteine or remethylated to methionine. Remethylation to methionine requires the cofactors, folate and vitamin $\mathrm{B}_{12}$. Folate is an effective homocysteinelowering agent and, thus, homocysteine and folate status are inversely related. Hyperhomocysteinaemia is a strong independent risk factor for venous thromboembolism (VTE) and is associated with adverse pregnancy outcomes such as pre-eclampsia, placental abruption, early pregnancy loss and neural-tube defects. Pregnancy is a risk factor for VTE as a result of prothrombotic changes in levels of haemostatic factors. However, despite this hypercoagulable state, the incidence of pregnancy-associated VTE is relatively low. Hyperhomocysteinaemia is associated with abnormalities in markers of coagulation activation, and recent research suggests that folic acid supplementation, as well as lowering homocysteine, lowers markers of coagulation activation and increases levels of coagulation inhibitors. Tissue factor (TF) is the initiator of blood coagulation in vivo, and homocysteine induces TF expression in vitro. During pregnancy, monocyte TF expression is lower than that in the non-pregnant state, and this lowering of TF may act to counterbalance increases in coagulation activation. Furthermore, despite a high folate requirement, several studies have reported that homocysteine is lower in normal pregnancy than in the non-pregnant state. Although the exact mechanism of homocysteine lowering during pregnancy is unclear, one possible outcome of lower homocysteine may be the protection of women from pregnancy complications and VTE, and thus lower homocysteine may contribute to maintaining homeostasis in haemostasis.
\end{abstract}

Homocysteine: Haemostasis: Pregnancy

\section{Homocysteine}

Homocysteine is a non-protein-forming thiol-containing amino acid derived from the demethylation of the essential amino acid methionine. Intracellular metabolism of homocysteine is regulated by two pathways, by which it is either further catabolised by trans-sulfuration to cysteine or remethylated to methionine. The trans-sulfuration pathway involves the enzyme cystathionine $\beta$-synthase and requires vitamin $\mathrm{B}_{6}$ as a cofactor. Remethylation to methionine is catalysed by methionine synthase, which requires folate in the form of 5-methyltetrahydrofolate as a co-substrate and vitamin $\mathrm{B}_{12}$ in the form of methylcobalamin as a cofactor (Finkelstein, 2000). Methylenetetrahydrofolate reductase (MTHFR) is a crucial enzyme in the remethylation pathway, and is responsible for converting 5,10-methylenetetrahydrofolate to the co-substrate 5-methyltetrahydrofolate.
In the absence of renal disease and hyperproliferative disorders, elevated levels of plasma homocysteine are generally a result of either a genetic defect in one of the enzymes involved in homocysteine metabolism or a nutritional deficiency of one of the vitamins that acts as a cofactor or co-substrate (folic acid, vitamin $\mathrm{B}_{12}$ and vitamin $\mathrm{B}_{6}$ ). Severe elevations in plasma homocysteine leading to homocystinuria are most commonly the result of a deficiency of the trans-sulfuration enzyme cystathionine $\beta$-synthase (Mudd et al. 1985), whereas mild elevations in homocysteine, known as hyperhomocysteinaemia, are associated with a common mutation in the MTHFR gene (Frosst et al. 1995). This autosomal recessive mutation is a $\mathrm{C} \rightarrow \mathrm{T}$ substitution at base pair 677 resulting in an alanine to valine substitution and, as a consequence, in vivo enzyme activity is impaired. Individuals who are homozygous for

\footnotetext{
Abbreviations: AT, antithrombin III; F1+2, prothrombin fragments 1+2; MTHFR, methylenetetrahydrofolate reductase; PAI, plasminogen activator inhibitor; TAT, thrombin-antithrombin; TM, thrombomodulin; TF, tissue factor; t-PA, tissue plasminogen activator; VTE, venous thromboembolism; vWF, von Willebrand factor.

Corresponding author: Dr Valerie Holmes, present address Department of Medicine, Queen's University Belfast, Mulhouse, Grosvenor Road, Belfast BT12 6BJ, UK, fax +44 2890 235900, email v.holmes@qub.ac.uk
} 
the $677 \mathrm{C} \rightarrow \mathrm{T}$ polymorphism (TT genotype; $5-18 \%$ of the population) tend to have elevated homocysteine levels when compared with individuals who are heterozygous for the mutation (CT genotype) or without the mutation (CC genotype; Frosst et al. 1995; Brattström et al. 1998).

Homocysteine and folate status are inversely related (Kang et al. 1987; Andersson et al. 1992a; Selhub et al. 1993; Ueland et al. 1993), with extensive research showing that homocysteine can be lowered in response to folic acid supplementation (Homocysteine Lowering Trialists' Collaboration, 1998), and that this lowering of homocysteine can be achieved with a dose as low as $200 \mu \mathrm{g}$ folic acid/d (Ward et al. 1997). In addition, several studies have demonstrated that vitamin $\mathrm{B}_{12}$ and vitamin $\mathrm{B}_{6}$ are effective in lowering homocysteine, and indeed may enhance the homocysteine-lowering effect of folic acid (Ubbink et al. 1994; Brönstrup et al. 1998; Homocysteine Lowering Trialists' Collaboration, 1998; McKinley et al. 2001; Quinlivan et al. 2002).

The normal range of fasting homocysteine in adults is 5-15 $\mu \mathrm{mol} / 1$ (Ueland et al. 1993), although Ubbink et al. (1995) proposed a range of $4 \cdot 9-11 \cdot 7 \mu \mathrm{mol} / 1$, which represents the normal range in a population with optimum B-vitamin status. Plasma homocysteine concentrations increase with age and are higher in men than in women, with levels becoming more comparable after menopause (Andersson et al. 1992a; Nygård et al. 1995). Smoking and coffee consumption are also associated with elevated plasma homocysteine (Nygård et al. 1995, 1997, 1998). Homocysteine concentrations increase after moderate consumption of red wine and spirits, but not after moderate consumption of beer, and it is proposed that the vitamin $\mathrm{B}_{6}$ in beer prevents the alcohol-induced rise in homocysteine (van der Gaag et al. 2000).

\section{Folate and homocysteine in normal pregnancy}

\section{Folate and pregnancy}

Pregnant women have a high folate requirement and are at an increased risk of folate deficiency as a result of increased folate catabolism and utilisation (McPartlin et al. 1993). Folate-responsive megaloblastic anaemia is reported in $2 \cdot 5-5 \cdot 0 \%$ of unsupplemented pregnancies in the developed world, with as many as $25 \%$ of women from otherwise well-nourished societies developing bone marrow megaloblastosis, which is indicative of subclinical folate deficiency (Chanarin, 1985). Folate status of the mother also has implications for her offspring. Rolschau et al. (1979) reported a positive correlation between folate status and birth weight, and between folate status and placental weight. Furthermore, in a recent study Rolschau et al. (1999) demonstrated that folic acid supplementation is associated with increased birth weight and a reduction in incidence of preterm labour and the number of infants with low birth weight or who were small-for-gestational age.

Spina bifida and anencephaly are severe congenital malformations referred to as neural-tube defects, resulting from incomplete closure of the spinal cord and cranium respectively in the fourth week of embryonic life. Confirming previous suggestions, the Medical Research
Council Vitamin Study Research Group (1991) reported that periconceptual folic acid effectively prevents the recurrence of neural-tube defects. A subsequent study by Czeizel \& Dudas (1992) confirmed that folic acid also prevents firsttime occurrence of neural-tube defects. In response to this evidence national expert committees advised the current recommendations: $4-5 \mathrm{mg} / \mathrm{d}$ folic acid in tablet form for the prevention of neural-tube defect recurrence; $400 \mu \mathrm{g}$ folic $\mathrm{acid} / \mathrm{d}$, to be commenced before conception and continued until the twelfth week of pregnancy for the prevention of first occurrence (Department of Health, 1992; Public Health Services, Centre for Disease Control and Prevention, 1992).

\section{Homocysteine and pregnancy}

Despite the increased risk of folate deficiency during pregnancy, several studies, predominantly of an observational design, have reported that homocysteine is lower in normal pregnancy than in the non-pregnant state (Kang et al. 1986; Anderson et al. 1992b; Bonnette et al. 1998; Walker et al. 1999; Quinlivan et al. 2000).

The reduction in homocysteine observed in pregnancy may not simply be attributed to a single factor, but is most likely to be a physiological effect of pregnancy, with several factors contributing. It is possible that hormonal changes in pregnancy play a substantial role in the regulation of homocysteine, given that hormone-replacement therapy reduces levels of homocysteine in post-menopausal women (Mijatovic et al. 1998a,b; van Baal et al. 1999; Somekawa et al. 2002). Furthermore, Morris et al. (2000), in the Third National Health and Nutrition Examination Survey, concluded that higher oestrogen status is associated with decreased homocysteine concentration, independent of nutritional status and muscle mass. For a comprehensive review of oestrogen and homocysteine, see Dimitrova et al. (2002).

Another possible cause of lower homocysteine during pregnancy may be the uptake of homocysteine by the fetus. Malinow et al. (1998) demonstrated a descending concentration gradient of plasma homocysteine from maternal vein to umbilical vein and to umbilical artery, suggestive of the likely incorporation of homocysteine into the fetal metabolic cycle and, thus, of utilisation by the fetus. Haemodilution is yet another possible factor resulting in lower homocysteine, as during normal pregnancy plasma volume expands, with levels at 12 weeks of gestation increased by $14 \%$ over follicular-phase measurements (Bernstein et al. 2001). However, it is unlikely that haemodilution can account entirely for lower levels of homocysteine in normal pregnancy, as levels are at least $30 \%$ lower in the first trimester than those of non-pregnant control subjects (Anderson et al. 1992b; Bonnette et al. 1998; Walker et al. 1999), indicating that some other factors must be involved. Albumin binds $70 \%$ of the homocysteine in human plasma (Refsum et al. 1985), and as plasma albumin levels fall progressively over the duration of pregnancy (Anderson et al. 1992b; Walker et al. 1999), decreased plasma albumin may also contribute to lower homocysteine levels.

As folic acid is an established homocysteine-lowering agent (Homocysteine Lowering Trialists' Collaboration, 
1998), it is possible that folic acid supplementation during pregnancy may also lower homocysteine. However, there has been little research investigating the effect of folic acid on homocysteine levels during pregnancy. Although there is still some debate about which factors contribute, it is accepted that lower levels of homocysteine are found during normal pregnancy. The possible advantages of these lower homocysteine levels are discussed later.

\section{Normal haemostasis}

Haemostasis has evolved in order to maintain the integrity of the vasculature. Although it has been known since the time of Hippocrates and Aristotle that blood has the ability to clot, it was not until the 1730s that a Parisian surgeon, Jean-Louis Petit, related blood clotting to haemostasis (Owen, 2001). In the 19th century Rudolf Virchow (1860) first described the phenomena now known as deep-vein thrombosis and pulmonary embolism. When Morawitz (1905) reviewed the classic theory of coagulation there were four coagulation factors: fibrinogen; prothrombin; thromboplastin; Ca. Subsequently, the cascade (Macfarlane, 1964) and waterfall (Davie \& Ratnoff, 1964) theories of blood coagulation described two alternative pathways, the 'extrinsic' and the 'intrinsic', which merged to form a 'common' pathway. The current revised scheme of blood coagulation is known as the tissue factor (TF) pathway (Nemerson, 1988; Rapaport \& Rao, 1995; Fig. 1). Normal haemostasis is a complex network of interactions with positive and negative feedback loops, integrating blood vessels, platelets, coagulation factors, coagulation inhibitors and fibrinolysis, so that thrombin generation and subsequent fibrinolysis and remodelling are focused and finite.

Blood vessels and platelets are essential components of normal haemostasis. The endothelium of blood vessels has anticoagulant and fibrinolytic properties, as well as the ability to prevent platelet aggregation, and thus plays a vital role in maintaining blood flow. Platelets are activated in response to blood vessel damage or exposure to foreign surfaces, leading to shape change, secretion of platelet granule contents, platelet adhesion and platelet aggregation. Coagulation factors assemble and interact on the surface of the activated platelets, reinforcing the platelet plug with fibrin. George (2000) and van Hinsbergh (2001) reviewed the roles of platelets and the endothelium in normal haemostasis.

\section{Coagulation factors and blood coagulation}

Blood coagulation is initiated by TF, a transmembrane glycoprotein constitutively expressed by non-vascular cells such as alveolar epithelial cells of the lung (Drake et al. 1989), thus forming a haemostatic envelope. Within the vasculature, TF expression can be induced on monocytes and endothelial cells by the inflammatory cytokines tumour necrosis factor- $\alpha$, interferon- $\gamma$ and interleukin-1 $\beta$ (Schwagner

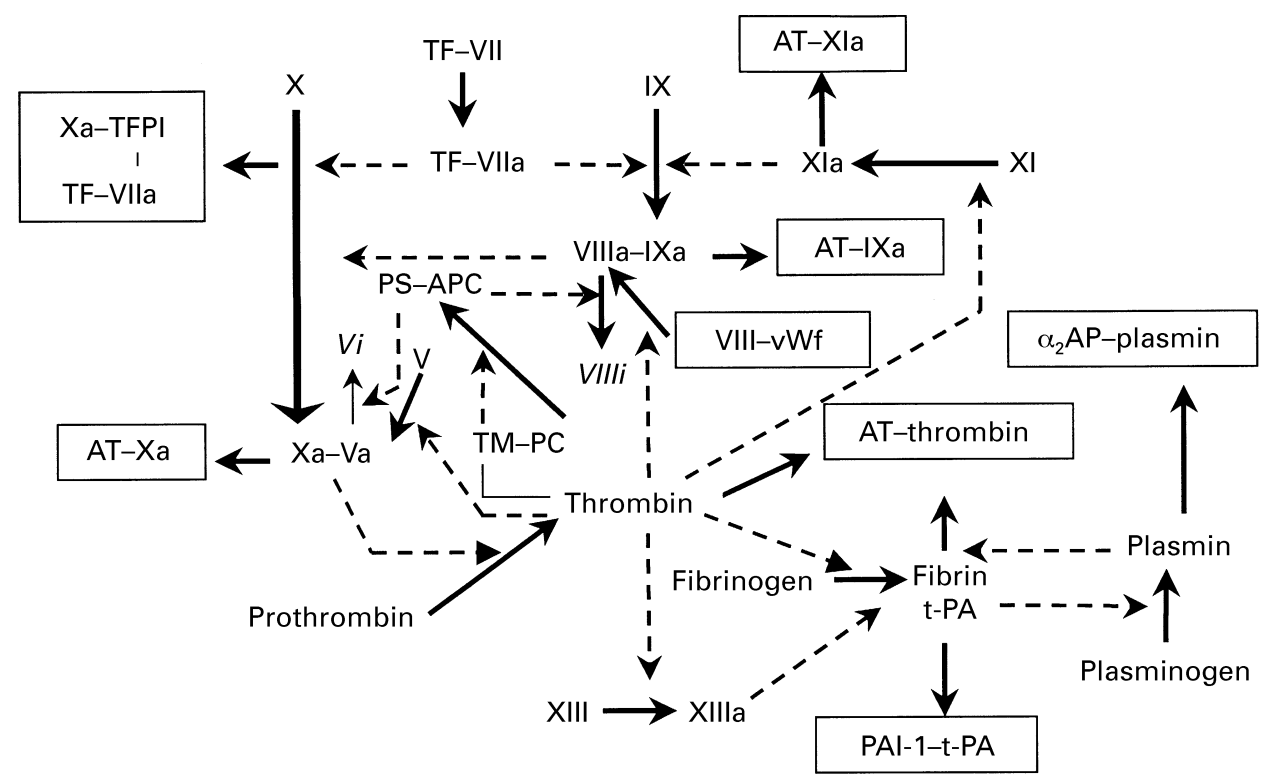

Fig. 1. Coagulation cascade: Tissue factor (TF) - factor VIla complex initiates the coagulation cascade, activating factor $\mathrm{X}(\mathrm{X} \rightarrow \mathrm{Xa})$ and leading to thrombin generation. Thrombin activates factors $\mathrm{XI}, \mathrm{XIII}, \mathrm{V}$ and VIII, releasing factor VIII from its inactive complex with von Willebrand factor (vWF). Factor Xla activates IX, and sequentially the VIIIa-IXa and Va-Xa complexes result in further thrombin generation. Thrombin converts fibrinogen to fibrin, while XIIla cross-links fibrin to stabilise the clot. Coagulation inhibitors: TF pathway inhibitor (TFPI) inactivates the TF-VIla-Xa complex, while antithrombin (AT) inactivates thrombin and IXa. Thrombin binds thrombomodulin (TM), activating protein $C(P C \rightarrow A P C)$. APC binds protein S (PS), degrading Va and VIIIa $(\mathrm{Va} \rightarrow \mathrm{Vi}$; VIIla $\rightarrow$ VIIII). Fibrinolysis: Fibrin binds tissue plasminogen activator (t-PA), converting plasminogen to plasmin, which degrades fibrin to fibrin degradation products. Plasmin is inactivated by $\alpha_{2}$-antiplasmin $\left(\alpha_{2} \mathrm{AP}\right)$, while plasminogen activator inhibitor (PAI-1) inactivates t-PA. Inhibited complexes are represented in boxes $(\rightarrow)$, changes of state; $(-\rightarrow)$, proteolytic activation-inactivation. (Modified from Hutton et al. 1999.) 
\& Jungi, 1994) and interleukins 6 and 8 (Neuman et al. 1997), and by endotoxin (Colucci et al. 1983), C-reactive protein (Cermak et al. 1993) and homocysteine (Khajuria \& Houston, 2000). When TF is exposed to blood, following vessel injury or possibly following cytokine induction of $\mathrm{TF}$, it forms a proteolytically-active complex with factor VII. Factor VII, an inactive zymogen, circulates in plasma and is activated to VIIa when complexed with TF. The TF-VIIa complex catalyses the activation of factor IX to $\mathrm{IXa}$, as well as catalysing a marked amount of factor $\mathrm{X}$ to $\mathrm{Xa}$. Factor $\mathrm{Xa}$ activates factor $\mathrm{V}$ in sufficient amounts to activate prothrombin to thrombin, which in turn activates factors V, VIII and XI. Factor VIIIa forms a complex with $\mathrm{IXa}$, which further activates $\mathrm{X}$ to $\mathrm{Xa}$, resulting in the generation of more thrombin, leading to fibrin clot formation (Hutton et al. 1999; see Fig. 1).

\section{Inhibitors of blood coagulation}

Coagulation inhibitors are necessary to ensure that thrombin generation remains limited and localised. Antithrombin III (AT), heparin, heparin cofactor II, $\alpha_{1}$-antitrypsin, $\alpha_{2-}$ macroglobulin and TF pathway inhibitor inhibit the serine proteases of the coagulation cascade, such as thrombin, $\mathrm{Xa}$ and TF-VIIa. Protein C, thrombomodulin (TM), protein S, $\mathrm{C} 4 \mathrm{~b}$-binding protein and activated protein $\mathrm{C}$ inhibitor are all components of the protein $\mathrm{C}$ system. TM bound to thrombin activates protein $\mathrm{C}$, which rapidly degrades factors VIIIa and $\mathrm{Va}$ on the phospholipid surface of activated platelets, a reaction that increases $10-20$-fold when protein $\mathrm{C}$ combines with its cofactor protein $\mathrm{S}$.

\section{Fibrinolysis}

Fibrinolysis controls fibrin deposition, thus maintaining a controlled procoagulant response. Fibrinolysis involves the conversion of plasminogen to plasmin by tissue plasminogen activator (t-PA). Plasmin cleaves fibrin and fibrinogen, yielding fibrin degradation products. $\alpha_{2}$ Antiplasmin, a plasmin inhibitor, and plasminogen activator inhibitor (PAI) types 1 and 2 prevent excess fibrinogen degradation by plasmin. Endothelial cells are regulators of fibrinolytic activity, as they synthesise t-PA and PAI-1 (Hajjar, 1993).

\section{Markers of haemostasis activation}

Normal haemostasis requires a balance between coagulation and fibrinolysis. A shift in the haemostatic balance can result in either a tendency to bleed or hypercoagulability with increased risk of thromboembolism. The hypercoagulable condition is difficult to detect with routine laboratory assays, and requires the use of sensitive activation markers of coagulation and fibrinolysis such as prothrombin fragments $1+2(\mathrm{~F} 1+2)$, thrombin-antithrombin (TAT) complex (Bauer, 1999) and D-dimers (Whitaker et al. 1985). F1+2, cleaved from prothrombin after its activation by factor $\mathrm{Xa}$, and TAT, formed during inactivation by its main inhibitor antithrombin, are markers of coagulation, whereas D-dimers are products of fibrin breakdown by plasmin and thus are markers of fibrinolysis.

\section{Haemostasis in normal pregnancy}

Normal pregnancy is associated with substantial changes in the haemostatic system, with pregnancy often referred to as a hypercoagulable state. Traditionally, it is thought that these changes are in preparation for the haemostatic challenge of delivery, with the haemostatic system returning to that of the non-pregnant state at approximately 4 weeks post delivery (Greer, 1994). In the present review alterations in coagulation factors, coagulation inhibitors, fibrinolysis and markers of haemostasis will be discussed in turn. Greer (1994) and Lyall \& Greer (1996) reviewed alterations in platelets, platelet function and the endothelium during normal pregnancy.

\section{Coagulation factors}

During normal pregnancy factor XIII, fibrin-stabilising factor, increases in the early stages of pregnancy, returning to non-pregnant values in the third trimester (Persson et al. 1980; van Wersch et al. 1997). Levels of factor XII rise progressively during the gestation period (Hellgren \& Blombäck, 1981; de Moerloose et al. 1998a; Donohoe et al. 2002), as do levels of factor X (Hellgren \& Blombäck, 1981; Stirling et al. 1984). Conversely, levels of factor XI decrease during pregnancy (Hellgren \& Blombäck, 1981), possibly as the result of increased factor XI consumption (Blombäck, 1991). However, given that activation of factor $\mathrm{XI}$ by thrombin is required to activate factor IX leading to further thrombin generation, it is possible that in normal pregnancy levels of factor XI are physiologically lowered to counterbalance the increases in other coagulation factors.

Factor VIII levels and coagulation activity rise progressively during pregnancy (Hellgren \& Blombäck, 1981; Stirling et al. 1984; Chan et al. 1985; Bokarewa et al. 1997; Walker et al. 1997; Clark et al. 1998; Kjellberg et al. 1999), as do levels of von Willebrand factor (vWF) (Hellgren \& Blombäck, 1981; Stirling et al. 1984; Chan et al. 1985). The vWF:VIII coagulation activity value remains constant until the third trimester, after which the value increases, suggesting an increase in proteolytic degradation of activated VIII in the later stages of pregnancy (Hellgren \& Blombäck, 1981; Stirling et al. 1984). There is a gradual increase in factor VII during normal pregnancy (Stirling et al. 1984; de Moerloose et al. 1998a; Wright et al. 1998; Donohoe et al. 2002). The increase in factor $\mathrm{V}$ concentration in early pregnancy is followed by a decrease and stabilisation (Stirling et al. 1984), while factor $\mathrm{V}$ coagulation activity shows a gradual rise throughout gestation (Clark et al. 1998). Studies of prothrombin (factor II) levels in pregnancy have yielded inconclusive results, showing both increases (Stirling, 1984) and no change (Clark et al. 1998) during pregnancy. Fibrinogen levels show a steady increase during pregnancy (Hellgren \& Blombäck, 1981; Stirling et al. 1984; Gatti et al. 1994; Francalanci et al. 1995; Cerneca et al. 1997; Kjellberg et al. 1999).

Finally, while levels of soluble TF remain constant during normal pregnancy (Bellart et al. 1998), monocyte TF activity and expression are lower in normal pregnancy than in non-pregnant control subjects (Øian et al. 1985; Holmes et al. 2002). As TF is the initiator of blood clotting in vivo, 
lower TF expression and activity on circulating monocytes may play an important role in protecting pregnant women from venous thromboembolism (VTE), despite increases in many of the clotting factors and the hypercoagulable state described earlier (Holmes et al. 2002).

\section{Coagulation inhibitors}

Levels of AT remain stable during pregnancy (Hellgren \& Blombäck, 1981; Stirling et al. 1984; Gerbasi et al. 1990; Bremme et al. 1992; Gatti et al. 1994; Francalanci et al. 1995; Bellart et al. 1997; Cerneca et al. 1997), while heparin cofactor II, TM, $\alpha_{1}$-antitrypsin and $\alpha_{2}$-macroglobulin levels are raised during normal pregnancy (Stirling et al. 1984; Massouh et al. 1989; Bellart et al. 1997; de Moerloose et al. $1998 b)$. Little is known about levels of TF pathway inhibitor during normal pregnancy. However, levels are lower during labour than in non-pregnant controls (Uszynski et al. 2001). Levels of total and free protein $\mathrm{S}$ gradually decrease throughout pregnancy (Comp et al. 1986; Malm et al. 1988; Fernandez et al. 1989; Bremme et al. 1992; Gatti et al. 1994; Faught et al. 1995; Cerneca et al. 1997; Clark et al. 1998; Kjellberg et al. 1999). The majority of studies report that levels of protein $\mathrm{C}$ remain constant during normal pregnancy (Bremme et al. 1992; Gatti et al. 1994; Faught et al. 1995; Cerneca et al. 1997; Clark et al. 1998; Kjellberg et al. 1999), yet acquired activated protein $\mathrm{C}$ resistance is reported in up to $57 \%$ of normal pregnancies (Cumming et al. 1995; Mathonnet et al. 1996; Schlit et al. 1996; Bokarewa et al. 1997; Peek et al. 1997; Walker et al. 1997; Clark et al. 1998; Kjellberg et al. 1999; Shu et al. 2000). This increase in activated protein $\mathrm{C}$ resistance corresponds with increases in factor VIII and decreases in protein $\mathrm{S}$ and activated protein C inhibitor (Bokarewa et al. 1997; Walker et al. 1997; Clark et al. 1998; Shu et al. 2000). Normal pregnancy appears to be associated with bi-directional changes in levels or activity of coagulation inhibitors, and it is possible that these complex changes occur in order to maintain the coagulation-fibrinolysis balance during normal pregnancy.

\section{Fibrinolysis}

Lower levels of t-PA have been reported in normal pregnancy compared with the non-pregnant state (Wright et al. 1988; Cerneca et al. 1997; Kjellberg et al. 1999). In addition, levels of endothelial-derived PAI-1, the primary inhibitor of t-PA, are increased during the later stages of pregnancy, while placenta-derived PAI-2, detectable in the plasma during the first trimester, increases substantially throughout pregnancy (Wright et al. 1988; Estelles et al. 1989; van Wersch \& Ubachs, 1991; Cerneca et al. 1997; Kjellberg et al. 1999). Plasminogen levels are increased during pregnancy, as are levels of the plasmin inhibitor $\alpha_{2}$-antiplasmin (Hellgren $\&$ Blombäck, 1981; Wright et al. 1988; van Wersch \& Ubachs, 1991). Overall, these changes suggest that the fibrinolytic system is impaired during normal pregnancy.

\section{Markers of haemostasis activation}

During normal pregnancy the changes in coagulation factors, coagulation inhibitors and components of the fibrinolytic system, as outlined earlier, are suggestive of a hypercoagulable state, with impaired fibrinolysis. Recent studies have concentrated on measuring markers of haemostasis activation, where TAT and $\mathrm{F} 1+2$ are measures of coagulation activation and fibrin degradation products and D-dimers are measures of fibrinolytic activation. During normal pregnancy, levels of TAT and F1+2 increase progressively, indicative of a substantial increase in coagulation activation (Bremme et al. 1992; Comeglio et al. 1996; Schlit et al. 1996; Cerneca et al. 1997; Clark et al. 1998; Reber et al. 1998; Eichinger et al. 1999; Kjellberg et al. 1999; Donohoe et al. 2002). Similarly, fibrinopeptide A, another marker of coagulation activation, is increased during pregnancy (Douglas et al. 1982; Gerbasi et al. 1990; Schlit et al. 1996; Bellart et al. 1998).

Despite the apparent impairment in fibrinolysis discussed earlier, normal pregnancy is associated with increases in fibrin degradation products and D-dimers (Gerbasi et al. 1990; Bremme et al. 1992; Francalanci et al. 1995; Schlit et al. 1996; Bellart et al. 1998; Eichinger et al. 1999; Kjellberg et al. 1999; Donohoe et al. 2002), indicative of a substantial increase in fibrinolytic system activation. As previously stated, normal haemostasis requires a balance between coagulation and fibrinolysis, and despite the marked changes in haemostasis associated with normal pregnancy, the incidence of VTE remains relatively low. According to Eichinger et al. (1999), levels of coagulation and fibrinolytic indices in healthy pregnant women in the third trimester are similar to, or higher than, those found in patients following a deep-vein thrombosis or pulmonary embolism, yet none of the women in this study developed clinical symptoms of VTE. Eichinger et al. (1999) also demonstrated that the endogenous thrombin potential, an indicator of the potency of plasma to generate thrombin in response to a thrombogenic stimulus (Hemker \& Beguin, 1995), remained unchanged throughout pregnancy. Moreover, the fibrinopeptide A:D-dimer ratio also remains constant throughout pregnancy, demonstrating a constant coagulation-fibrinolysis balance during normal pregnancy (Bellart et al. 1998). In contrast, a high fibrinopeptide A:Ddimer ratio, suggestive of hypofibrinolysis, was observed in women with pre-eclampsia (Bellart et al. 1999), thus highlighting the importance of the coagulation-fibrinolysis balance during normal pregnancy.

\section{Thrombosis in pregnancy}

\section{Venous thromboembolic disease in pregnancy}

Pregnancy and the puerperium are known risk factors for venous thrombosis (Rosendaal, 1999). Virchow's (1860) triad postulates that the principal factors underlying venous thrombosis are hypercoagulability, venous stasis and vascular damage, all of which occur during pregnancy (Greer, 1999). The hypercoagulable state is evident throughout pregnancy, venous stasis of the lower limbs occurs by the end of the first trimester (Macklon et al. 1997), and the potential for vessel damage is present during delivery. Although maternal death is rare, pulmonary embolism remains the leading cause of maternal death in the UK (Confidential Enquiries into Maternal Deaths, 2000). 
The incidence of VTE during normal pregnancy is estimated to be 5.5-6.0 times higher than that in the general female population of child-bearing age (McColl et al. 1997), with the reported incidence of pregnancy-associated VTE estimated at between 0.62 and 1.88 per 1000 deliveries (Macklon \& Greer, 1996; McColl et al. 1997; Gherman et al. 1999; Lindqvist et al. 1999; Chan et al. 2001; Simpson et al. 2001). The incidence of deep-vein thrombosis and pulmonary embolism is estimated at 0.71 and $0 \cdot 15$ per 1000 deliveries respectively, with the majority of deep-vein thrombosis events occurring in the antenatal period (McColl et al. 1997; Gherman et al. 1999). Although Gherman et al. (1999) reported that almost half antenatal deep-vein thrombosis events were detected before 15 weeks of gestation, the puerperium should be regarded as the period of greatest risk (McColl et al. 1997).

Clinical risk factors linked with pregnancy-associated VTE include advanced maternal age, high parity, weight, multiple birth, major current illness, operative delivery and pre-eclampsia (Macklon \& Greer 1996; McColl et al. 1999; Simpson et al. 2001). Personal or family history of thromboembolic disease is a recognised risk factor for VTE, with evidence of a genetic predisposition to VTE emerging. In one study approximately $30 \%$ of patients with confirmed VTE associated with pregnancy were found to have a heritable thrombophilia (McColl et al. 1997). Inherited or congenital thrombophilia, discussed by Rosendaal (1999), includes deficiencies of $\mathrm{AT}$, protein $\mathrm{C}$ and protein $\mathrm{S}$, and the presence of factor V Leiden, prothrombin 20210, and homozygosity for the thermo-labile variant of MTHFR. McColl et al. (1999) reviewed the role of inherited thrombophilia in pregnancy-associated VTE. Venous thrombosis is a multicausal disease, with interaction between genetic and acquired risk factors (Rosendaal, 1999), yet $28 \%$ of pregnancy-associated VTE are not related to either a clinical risk factor for thrombosis or a thrombophilic defect (McColl et al. 1997). Thus, it is possible that other unknown factors may contribute to the increased risk of VTE in pregnancy, highlighting the need for further research into changes in haemostasis during pregnancy.

\section{Homocysteine, methylenetetrahydrofolate reductase status and venous thromboembolism in pregnancy}

Hyperhomocysteinaemia is a known risk factor for venous thrombosis (Falcon et al. 1994; den Heijer et al. 1996; Eichinger et al. 1998; Ray et al. 2001). Little is known about the relationship between homocysteine and pregnancyassociated VTE, and given that homocysteine can be lowered by folic acid supplementation (Homocysteine Lowering Trialists' Collaboration, 1998), it is apparent that further studies investigating homocysteine and pregnancy associated-VTE are required.

In relation to the $677 \mathrm{C} \rightarrow \mathrm{T}$ MTHFR polymorphism and risk of VTE, it is still unclear if homozygosity for this mutation is a risk factor, with some studies reporting an association (Gemmati et al. 1999a; Salomon et al. 1999; Couturaud et al. 2000), while others found no association (Kluijtmans et al. 1998; Gemmati et al. 1999b; Alhenc-Gelas et al. 1999; Ray et al. 2001). Given that hyperhomocysteinaemia is a risk factor for VTE, it is not yet apparent why the relationship between the $677 \mathrm{C} \rightarrow \mathrm{T}$ MTHFR polymorphism and risk of VTE remains controversial. Kluijtmans et al. (1998) discussed several possible explanations; however, a meta-analysis of the data would be beneficial in determining any relationship. Similarly, in pregnant women it is unclear whether the $677 \rightarrow \mathrm{T}$ MTHFR polymorphism confers a risk of VTE, with McColl et al. (2000) finding no association, while Grandone et al. (1998) reported an increased risk of pregnancy-related VTE in homozygous individuals, thus highlighting the need for further studies.

\section{Thrombophilia and pregnancy complications}

Complications of pregnancy such as pre-eclampsia, fetal loss, placental abruption and intrauterine growth retardation are associated with both acquired and congenital thrombophilia (Dekker et al. 1995; Preston et al. 1996; Grandone et al. 1998; Greer, 1999; Gris et al. 1999; Kupferminc et al. 1999). Evidence that heparin and low-dose aspirin therapy are effective in increasing rates of live births in women with a history of recurrent miscarriage (Rai et al. 1997) highlights the importance of procoagulant changes in the pathophysiology of recurrent miscarriage (Greer, 2001). Furthermore, in anti-phospholipid syndrome, a hypercoagulable state, intrauterine growth retardation and fetal distress leading to premature birth or fetal death are attributed to utero-placental insufficiency that is the result of multiple placental thrombi and infarcts (Gharavi et al. 2001). The role of inherited and acquired thrombophilia in severe pregnancy complications has been investigated with conflicting results. Many et al. (2001) reported an increased rate of placental vascular lesions in women with severe complications and thrombophilia, whereas other researchers found no significant difference between the placentas of women with adverse pregnancy outcomes with or without a thrombophilic defect (Mousa \& Alfirevicl, 2000; Sikkema et al. 2002). It may be that factors other than those normally investigated in a thrombophilia screen are responsible for the abnormal placental pathology associated with adverse pregnancy outcome, such as increased production of the fibrinolytic inhibitor PAI-1 (Sheppard \& Bonnar, 1999). These data, together with recent reports of increased procoagulant microparticles in women with a history of pregnancy loss (Laude et al. 2001), suggest that excessive coagulation in general may be responsible for adverse fetal outcome (Greer, 2001).

\section{Homocysteine, methylenetetrahydrofolate reductase status and pregnancy complications}

The link between homocysteine, MTHFR and neural-tube defects is well established (Steegers-Theunissen et al. 1994; Mills et al. 1995; Whitehead et al. 1995). However, for the purposes of the present review, prominence will be given to pregnancy complications and homocysteine-MTHFR status where the probable link is a thrombotic mechanism. Placental vasculopathy resulting in placental infarcts compromises the ureto-placental circulation and is thought to contribute to pregnancy complications. Recently, van der Molen et al. (2000) reported that elevated homocysteine 
concentration and homozygosity for the $677 \mathrm{C} \rightarrow \mathrm{T}$ MTHFR mutation are risk factors for placental vasculopathy. Furthermore, there is substantial evidence that elevated homocysteine concentration is associated with common pregnancy complications and adverse pregnancy outcome (de Vries et al. 1997; Ray \& Laskin, 1999; Vollest et al. 2000), such as pre-eclampsia (Dekker et al. 1995; Rajkovic et al. 1997; Powers et al. 1998; Cotter et al. 2001), placental abruption (Goddijn-Wessel et al. 1996) and recurrent early pregnancy loss (Wouters et al. 1993; Quèrè et al. 1998; Nelen et al. 2000).

As with MTHFR genotype and risk of VTE, the association between risk of pregnancy complications and homozygosity for the $677 \mathrm{C} \rightarrow \mathrm{T}$ MTHFR mutation is more uncertain. In a study by Kupferminc et al. (1999) in which the study population comprised women with any one of the obstetrical complications (pre-eclampsia, placental abruption, intrauterine growth retardation or stillbirth), the frequency of TT genotype individuals was higher in cases than in controls. Grandone et al. (1997) reported an association between homozygosity for the $677 \mathrm{C} \rightarrow \mathrm{T}$ MTHFR mutation and the occurrence of pre-eclampsia and, although several other researchers have not found this association (Powers et al. 1999; Kaiser et al. 2001; D'Elia et al. 2002), a meta-analysis by Ray \& Laskin (1999) associated the TT genotype with a moderate risk of pre-eclampsia. Similarly, several authors found no association between placental abruption or fetal loss and homozygosity for the $677 \mathrm{C} \rightarrow \mathrm{T}$ MTHFR mutation (Brenner et al. 1999; Gris et al. 1999; Foka et al. 2000), while a meta-analysis reported that the TT genotype is a probable risk factor (Ray \& Laskin, 1999).

\section{Homocysteine and haemostasis}

\section{Coagulation factors}

There is increasing evidence that elevated levels of homocysteine are associated with prothrombotic changes in haemostatic factors. Rodgers \& Kane (1986) reported increased factor $\mathrm{V}$ activation in association with homocysteine-treated endothelial cells. In patients with acute coronary syndrome elevated plasma homocysteine has been associated with elevated factor VIIa (Al-Obaidi et al. 2000), although other researchers have been unable to demonstrate any correlation between factor VII activity and homocysteine in population-based studies (Kario et al. 2001; Kuch et al. 2001). The association between homocysteine and fibrinogen also remains unclear, with some researchers reporting an association (von Eckardstein et al. 1994; Kuch et al. 2001), and others finding no association (Folsom et al. 1998; Yarnell et al. 2000; Kario et al. 2001; Kuch et al. 2001). Kuch et al. (2001) studied two populations, Czech and German, and reported more pronounced associations between homocysteine and coagulation factors in the Czech population, which has a higher proportion of cardiovascular disease, and thus proposed that the association may become more apparent with underlying conditions that enhance and produce hypercoagulable states. In folic acid-supplementation studies Undas et al. (1999) reported no change in fibrinogen and prothrombin levels despite a reduction in homocysteine concentration, whereas other researchers reported decreases in both homocysteine and fibrinogen following supplementation (Naruszewicz et al. 2001; Mayer et al. 2002; Mayer Jr et al. 2002).

As well as playing a role in the coagulation pathway, vWF is an established marker of endothelial damage. Plasma vWF is increased in patients with hyperhomocysteinaemia (Freyburger et al. 1997; de Jong et al. 1997), and several studies have shown positive correlations between homocysteine and vWF (de Valk-de Roo et al. 1999; Becker et al. 2000; Yarnell et al. 2000; Kuch et al. 2001), although Kario et al. (2001) did not find any correlation. Similarly, results from folic acid-supplementation studies have not been consistent, with some studies demonstrating a decrease in $\mathrm{vWF}$ in association with homocysteine lowering (van den Berg et al. 1995; Mayer Jr et al. 2002), while other studies found no change in vWF levels (Constans et al. 1999; Thambyrajah et al. 2000, 2001). It may be that the inconsistency is the result of higher baseline homocysteine levels in studies in which homocysteine lowering was observed, possibly equating to damaged endothelium and higher baseline vWF levels, which were lowered or normalised on removal of the damaging stimulus, homocysteine. Furthermore, as study populations consisted of varying disease states, it is possible that, in some conditions, factors other than hyperhomocysteinaemia are involved in the pathophysiology of the prothrombotic state, thus leading to inconsistent results in supplementation studies.

In relation to $\mathrm{TF}$, the initiator of blood clotting in vivo, low concentrations of homocysteine have been shown to induce TF activity in endothelial cells (Fryer et al. 1993), while physiologically-relevant concentrations of homocysteine induce TF expression on monocytes (Khajuria \& Houston, 2000), thus presenting a plausible mechanism whereby homocysteine may induce thrombosis. Using a rat model, Durand et al. (1997) showed that hyperhomocysteinaemia enhances platelet aggregation and macrophage-derived TF activity. Moreover, homocysteine was positively correlated with plasma levels of TF in patients with IHD (Marcucci et al. 2000). However, only a randomised placebocontrolled folic acid-supplementation study designed to investigate whether homocysteine lowering by folic acid is accompanied by a reduction in $\mathrm{TF}$, will conclusively establish a cause-effect relationship between homocysteine and $\mathrm{TF}$ in vivo.

\section{Coagulation inhibitors}

Evidence is also emerging that elevated levels of homocysteine may result in prothrombotic changes in coagulation inhibitors. TM acts as a cofactor for thrombin-catalysed activation of protein $\mathrm{C}$, and in vitro studies have demonstrated that homocysteine inactivates TM activity, therefore reducing its anticoagulant properties (Lentz \& Sadler, 1991; Hayashi et al. 1992). TM is also a marker of endothelial damage and, in agreement with in vitro experiments (Hayashi et al. 1992), in vivo studies of patients with hyperhomocysteinaemia reported increased levels of TM when compared with normohomocysteinaemic patients (Hofmann et al. 1998; Brunelli et al. 2000), although this outcome has not been reported in all studies (de Jong et al. 1997; 
Kario et al. 2001). Results from folic acid-supplementation studies have shown that lowering of homocysteine is associated with a reduction in TM levels (van den Berg et al. 1995; Constans et al. 1999). The effects of homocysteine on TM demonstrate two mechanisms whereby homocysteine may contribute to thrombosis risk: increased endothelial damage; reduced anticoagulant properties.

In agreement with an early study reporting decreased AT activity in homocystinuric patients (Palareti \& Coccheri, 1989), Nishinaga et al. (1993) demonstrated that homocysteine suppresses anticoagulant heparan sulfate expression, thus reducing the capacity of endothelial cells to bind and activate the anticoagulant AT. However, several ex vivo studies found no correlation between plasma homocysteine concentrations and AT levels (Brattström et al. 1989; Bienvenu et al. 1991, 1993). Although Palareti \& Coccheri (1989) demonstrated that folic acid and pyridoxine treatment resulted in a return of AT activity to normal in homocystinuric patients, folic acid supplementation for treatment of hyperhomocysteinaemia has been reported to increase AT in some (Mayer et al. 2002; Mayer Jr et al. 2002), but not all (Undas et al. 1999), intervention studies.

Homocysteine also interferes with the protein $\mathrm{C}$ pathway. In vitro, supraphysiological concentrations of homocysteine reduce protein $\mathrm{C}$ activation by acting as a competitive inhibitor to thrombin (Rodgers \& Conn, 1990) and by irreversibly inactivating protein C (Lentz \& Sadler, 1991). More recently, Undas et al. (2001) demonstrated that homocysteine is rapidly incorporated into factor $\mathrm{Va}$, resulting in impaired inactivation of factor $\mathrm{Va}$ by activated protein $\mathrm{C}$, and that this process can occur at physiologically-relevant concentrations. Furthermore, Lentz et al. (1996) showed that the aortic endothelium from monkeys with hyperhomocysteinaemia activated protein $\mathrm{C}$ in vitro less effectively than that of control animals. However, in human studies elevated levels of homocysteine do not appear to affect protein $\mathrm{C}$ activation (Cattaneo et al. 1998), and folic acid treatment has no effect on the activity of protein $\mathrm{C}$ (Undas et al. 1999). It is unclear why there is a discrepancy between in vitro and in vivo results. One explanation may be that circulating activated protein $\mathrm{C}$ measured in vivo reflects protein $\mathrm{C}$ activation occurring in the microcirculation, and that there is a different relationship for activated protein $\mathrm{C}$ measured in vitro, which reflects localised activity (Cattaneo et al. 1998).

Overall, it is not clear why some studies link elevated homocysteine with impaired anticoagulation, whereas others show no association, but it may be possible that in certain disease states factors other than, or including, homocysteine influence thrombotic mechanisms, and thus inconsistent results may be related to the different populations studied.

\section{Fibrinolysis}

Elevated homocysteine also appears to result in prothrombotic changes within the fibrinolytic system. In vitro, homocysteine impairs the ability of endothelial cells to generate plasmin by modulating annexin II, inhibiting t-PAannexin II assembly on the cell (Hajjar \& Jacovina, 1998), and thus reducing t-PA activity by $60 \%$ (Hajjar, 1993). Ling \& Hajjar (2000) proposed that the subsequent reduction in plasmin generation could underlie the prothrombotic activity associated with homocysteine in vivo. Although these results, together with those of in vitro experiments which reported no effect of homocysteine on t-PA mRNA levels (Midorikawa et al. 2000), suggest that homocysteine affects the activity rather than the expression of $\mathrm{t}-\mathrm{PA}$, results from in vivo studies are inconclusive. Several studies reported no significant difference in levels of t-PA antigen between individuals with and without hyperhomocysteinaemia (de Jong et al. 1997; Božič et al. 2000), and folic acid supplementation of hyperhomocysteinaemic patients resulted in no significant change in t-PA concentration (van den Berg et al. 1995). However, other studies have reported an association between homocysteine and t-PA concentration (Bienvenu et al. 1993; Lindgren et al. 1996; Kristensen et al. 1999). Furthermore, t-PA activity of hyperhomocysteinaemic patients was not found to be significantly different from that of normohomocysteinaemic patients (Božič et al. 2000). In order to increase our understanding of the effect of homocysteine on t-PA in vivo, further studies of the effect of homocysteine lowering on both t-PA antigen and activity are necessary.

In vitro, homocysteine increases PAI-1 gene expression (Midorikawa et al. 2000), yet the effect of homocysteine on PAI-1 in vivo remains unclear. There was no significant difference in either PAI-1 antigen or activity for hyperhomocysteinaemic individuals compared with normohomocysteinaemic individuals (de Jong et al. 1997; Božič et al. 2000), and there was no association between homocysteine and PAI-1 activity (Bienvenu et al. 1993). However, in renal transplant recipients Marcucci et al. (2001) reported a positive correlation and a reduction in PAI-1 levels and homocysteine concentration following folic acid supplementation. In a folic acid-supplementation study of a similar size involving haemodialysis patients, lowering homocysteine levels did not result in a reduction in PAI-1 (Kunz et al. 1999). Again, one possible explanation for these apparently inconsistent results may be that in different disease states the mechanisms contributing to the prothrombotic state are complex, such that lowering homocysteine in one population may lower PAI-1 levels, whereas in a different population other factors continue to impinge on fibrinolysis.

There is some evidence that homocysteine may impair fibrinolysis, which could represent one mechanism whereby homocysteine contributes to the increased risk of thrombosis. However, in view of the disparity in results from studies to date, there is clearly a need for further investigation of homocysteine lowering in vivo in order to fully elucidate the link between elevated homocysteine and fibrinolytic factors.

\section{Markers of haemostasis activation}

It is apparent from the evidence discussed earlier that elevated homocysteine is associated with changes in coagulation factors, coagulation inhibitors and fibrinolytic factors. However, in order to determine whether hyperhomocysteinaemia is associated with the hypercoagulable state, changes in the sensitive activation markers of coagulation and fibrinolysis, F1 +2, TAT and D-dimer, must be examined. 
Homocysteine is positively correlated with TAT in patients with IHD (Marcucci et al. 2000) and, although mildly increased homocysteine levels are associated with elevated levels of TAT in plasma, folic acid supplementation does not modify TAT levels (Freyburger et al. 1997). Treatment of hyperhomocysteinaemia with folic acid and vitamin $\mathrm{B}_{12}$ has been reported to reduce TAT, F1 +2 and also increase bleeding time (Undas et al. 1999). A positive correlation has been observed between homocysteine and $\mathrm{F} 1+2$ in patients with acute coronary syndromes, but not in patients who presented with chest pain that was not of cardiac origin (Al-Obaidi et al. 2000) or in asymptomatic populations (Kario et al. 2001; Kuch et al. 2001). In large population studies a positive correlation was found between homocysteine and D-dimer, demonstrating a relationship between homocysteine and fibrinolytic activity (Yarnell et al. 2000; Kuch et al. 2001). However, increased fibrinolysis is suggestive of increased coagulation and, therefore, it would be of greater relevance to observe the effect of elevated homocysteine on the coagulationfibrinolysis balance, perhaps by measuring the fibrinopeptide A:D-dimer ratio in subjects with elevated homocysteine, and observing the effect of homocysteinelowering treatment.

It is difficult to interpret the effect of elevated homocysteine on haemostasis as many in vitro studies use supraphysiological concentrations, and in vivo and ex vivo studies examine a variety of different populations with complex disease states. Thus, further prospective studies are required in order to fully establish whether homocysteine is associated with the hypercoagulable state as a causative agent or whether elevated levels of homocysteine are a product of other, unknown, mechanisms involved in the pathophysiology of thrombotic diseases.

The present review has sought to examine the effect of homocysteine on haemostasis, and also describes alterations in normal haemostasis and in homocysteine during normal pregnancy. Although to date there has been little research into the effect of homocysteine lowering in pregnancy on haemostatic factors, it is possible that this physiological lowering of homocysteine plays a homeostatic role in the regulation of haemostatic factors during an otherwise hypercoagulable period.

\section{Concluding statement}

In normal haemostasis there is a balance between coagulation factors and coagulation inhibitors, and between fibrinolytic factors and fibrinolytic inhibitors, with normal haemostasis ultimately being the result of a balance between coagulation and fibrinolysis. Although normal pregnancy is associated with many changes in haemostasis, with a potential tilt towards the hypercoagulable state, there is evidence that this balance is maintained (Bellart et al. 1998; Eichinger et al. 1999). In addition to increases in certain coagulation inhibitors and a decrease in factor XI (discussed earlier), the reduction in the expression of monocyte TF, the initiator of blood clotting in vivo, may play a major role in redressing the haemostatic balance (Holmes et al. 2002). As homocysteine induces monocyte TF expression at physiological concentrations in vitro (Khajuria \& Houston,
2000), it may be that reduced levels of plasma homocysteine during normal pregnancy play a role in down regulating $\mathrm{TF}$ expression and, thus, in maintaining homeostasis in haemostasis. The reason for lower homocysteine in pregnancy is unknown, but as elevated homocysteine is associated with prothrombotic changes in haemostasis and consequently with increased risk of pregnancy complications, one outcome of lower homocysteine may be the protection of the mother and fetus from VTE and pregnancy complications.

As folic acid is effective in lowering homocysteine, it is essential to investigate homocysteine metabolism in pregnancy and to establish the role of folate in homocysteine metabolism at the different stages of pregnancy. Finally, longitudinal prospective studies in pregnant women at risk of VTE or with pregnancy complications are necessary in order to fully evaluate the link between homocysteine and thrombotic complications associated with pregnancy.

\section{References}

Alhenc-Gelas M, Arnaud E, Nicaud V, Aubry ML, Fiessinger JN, Aiach M \& Emmerich J (1999) Venous thromboembolic disease and the prothrombin, methylene tetrahydrofolate reductase and factor V genes. Thrombosis and Haemostasis 81, 506-510.

Al-Obaidi MK, Philippou H, Stubbs PJ, Adami A, Amersey R, Noble MM \& Lane DA (2000) Relationships between homocysteine, factor VIIa, and thrombin generation in acute coronary syndromes. Circulation 101, 372-377.

Andersson A, Brattström L, Israelsson B, Isaksson A, Hamfelt A \& Hultberg B (1992a) Plasma homocysteine before and after methionine loading with regard to age, gender and menopausal status. European Journal of Clinical Investigation 22, 79-87.

Andersson A, Hultberg B, Brattström L \& Isaksson A (1992b) Decreased serum homocysteine in pregnancy. European Journal of Clinical Chemistry and Clinical Biochemistry 30, 377-379.

Bauer KA (1999) Activation markers of coagulation. Bailliere's Best Practice and Research in Clinical Haematology 12, 387-406.

Becker A, van Hinsbergh VW, Kostense PJ, Jager A, Dekker JM, Nijpels G, Heine RJ, Bouter LM \& Stehouwer CD (2000) Serum homocysteine is weakly associated with von Willebrand factor and soluble vascular cell adhesion molecule 1 , but not with C-reactive protein in type 2 diabetic and non-diabetic subjects - The Hoorn Study. European Journal of Clinical Investigation 30, 763-770.

Bellart J, Gilabert R, Anglès A, Piera V, Miralles RM, Monasterio J \& Cabero L (1999) Tissue factor levels and high ratio of fibrinopeptide A:D-dimer as a measure of endothelial procoagulant disorder in pre-eclampsia. British Journal of Obstetrics and Gynaecology 106, 594-597.

Bellart J, Gilabert R, Fontcuberta J, Borrell M, Miralles RM \& Cabero L (1997) Levels of coagulation inhibitors and thromin-antithrombin III complexes in normal pregnancy. Medical Science Research 25, 699-702.

Bellart J, Gilabert R, Miralles RM, Monasterio J \& Cabero L (1998) Endothelial cell markers and fibrinopeptide A to D-dimer ratio as a measure of coagulation and fibrinolysis balance in normal pregnancy. Gynecologic and Obstetric Investigation 46, 17-21.

Bernstein IM, Ziegler W \& Badger GJ (2001) Plasma volume expansion in early pregnancy. Obstetrics and Gynecology 9, 669-672.

Bienvenu T, Ankri A, Chadefaux B, Montalescot G \& Kamoun P (1993) Elevated total plasma homocysteine, a risk factor for thrombosis. Relation to coagulation and fibrinolytic parameters. Thrombosis Research 70, 123-129. 
Bienvenu T, Chadefaux B, Ankri A, Leblond V, Coude M, Salehian B, Binet JL \& Kamoun P (1991) Antithrombin III activity is not related to plasma homocysteine concentrations. Haemostasis $\mathbf{2 1}$, 65-67.

Blombäck M (1991) Changes in blood coagulation and fibrinolysis during pregnancy and the menstrual cycle: new methods for detecting the changes. Advances in Contraception 7, 259S-272S.

Bokarewa MI, Wramsby M, Bremme K \& Blombäck M (1997) Variability of the response to activated protein $\mathrm{C}$ during normal pregnancy. Blood Coagulation and Fibrinolysis 8, 239-244.

Bonnette RE, Caudill MA, Boddie AM, Hutson AD, Kauwell GPA \& Bailey LB (1998) Plasma homocyst(e)ine concentration in pregnant and non-pregnant women with controlled folate intake. Obstetrics and Gynecology 92, 167-170.

Božič M, Stegnar M, Fermo I, Ritonja A, Peternel P, Stare J \& D'Angelo A (2000) Mild hyperhomocysteinemia and fibrinolytic factors in patients with history of venous thromboembolism. Thrombosis Research 100, 271-278.

Brattström L, Israelsson B, Tengborn L \& Hultberg B (1989) Homocysteine, factor VII and antithrombin III in subjects with different gene dosage for cystathionine beta-synthase. Journal of Inherited Metabolic Disease 12, 475-482.

Brattström L, Wilcken DEL, Öhrvik J \& Brudin L (1998) Common methylenetetrahydrofolate reductase gene mutation leads to hyperhomocysteinemia but not to vascular disease - the result of a meta-analysis. Circulation 98, 2520-2526.

Bremme K, Ostlund E, Almqvist I, Heinonen K \& Blombäck M (1992) Enhanced thrombin generation and fibrinolytic activity in normal pregnancy and the puerperium. Obstetrics and Gynaecology 80, 132-137.

Brenner B, Sarig G, Weiner Z, Younis J, Blumenfeld Z \& Lanir N (1999) Thrombophilic polymorphisms are common in women with fetal loss without apparent cause. Thrombosis and Haemostasis 82, 6-9.

Brönstrup A, Hages M, Prinz-Langenohl R \& Pietrzik K (1998) Effects of folic acid and combinations of folic acid and vitamin B-12 on plasma homocysteine concentrations in healthy, young women. American Journal of Clinical Nutrition 68, 1104-1110.

Brunelli T, Prisco D, Fedi S, Rogolino A, Farsi A, Marcucci R, Giusti B, Pratesi C, Pulli R, Gensini GF, Abbate R \& Pepe G (2000) High prevalence of mild hyperhomocysteinemia in patients with abdominal aortic aneurysm. Journal of Vascular Surgery 32, 531-536.

Cattaneo M, Franchi F, Maddalena ZL, Martinelli I, Asti D \& Mannucci PM (1998) Plasma levels of activated protein C in healthy subjects and patients with previous venous thromboembolism. Relationships with plasma homocysteine levels. Arteriosclerosis, Thrombosis and Vascular Biology 18, 1371-1375.

Cermak J, Key NS, Bach RR, Balla J, Jacob HS \& Vercellotti GM (1993) C-reactive protein induces human peripheral blood monocytes to synthesise tissue factor. Blood 82, 513-520.

Cerneca F, Ricci G, Simeone R, Malisano M, Alberico S \& Guaschino S (1997) Coagulation and fibrinolysis changes in normal pregnancy. Increased levels of procoagulants and reduced levels of inhibitors during pregnancy induce a hypercoagulable state, combined with a reactive fibrinolysis. European Journal of Obstetrics and Gynaecology and Reproductive Biology 73, 31-36.

Chan LY, Tam WH \& Lau TK (2001) Venous thromboembolism in pregnant Chinese women. Obstetrics and Gynecology 98, 471-475.

Chan SY, Chan PH, Ho PC \& Yam A (1985) Factor VIII-related antigen levels in normal pregnancy and puerperium. European Journal of Obstetrics and Gynaecology and Reproductive Biology 19, 199-204.
Chanarin I (1985) Folate and cobalamin. Clinical Haematology 14, 629-641.

Clark P, Brennand J, Conkie JA, McCall F, Greer IA \& Walker ID (1998) Activated protein C sensitivity, protein C, protein S and coagulation in normal pregnancy. Thrombosis and Haemostasis 79, 1166-1170.

Colucci M, Balconi G, Lorenzet R, Pietra A, Locati D, Donati MB \& Semerara N (1983) Cultured human endothelial cells generate tissue factor in response to endotoxin. Journal of Clinical Investigation 71, 1893-1896.

Comeglio P, Fedi S, Liotta AA, Cellai AP, Chiarantini E, Prisco D, Mecacci F, Parretti E, Mello G \& Abbate R (1996) Blood clotting activation during pregnancy. Thrombosis Research 84, 199-202.

Comp PC, Thurnau GR, Welsh J \& Esmon CT (1986) Functional and immunologic protein $\mathrm{S}$ levels are decreased during pregnancy. Blood 68, 881-885.

Confidential Enquiries into Maternal Deaths (2000) Why Mothers Die 1997-1999. The Fifth Report of the Confidential Enquiries into Maternal Deaths in the United Kingdom. London: Royal College of Obstetricians and Gynaecologists.

Constans J, Blann AD, Resplandy F, Parrot F, Renard M, Seigneur M, Guérin V, Boisseau M \& Conri C (1999) Three months supplementation of hyperhomocysteinaemic patients with folic acid and vitamin B6 improves biological markers of endothelial dysfunction. British Journal of Haematology 107, 776-778.

Cotter AM, Molloy AM, Scott JM \& Daly SF (2001) Elevated plasma homocysteine in early pregnancy: A risk factor for the development of severe pre-eclampsia. American Journal of Obstetrics and Gynecology 185, 781-785.

Couturaud F, Oger E, Abalain JH, Chenu E, Guias B, Floch HH, Mercier B, Mottier D \& Leroyer C (2000) Methylenetetrahydrofolate reductase $\mathrm{C} 677 \mathrm{~T}$ genotype and venous thromboembolic disease. Respiration 67, 657-661.

Cumming AM, Tait RC, Fildes S, Yoong A, Keeney S \& Hay CR (1995) Development of resistance to activated protein C during pregnancy. British Journal of Haematology 90, 725-727.

Czeizel AE \& Dudas I (1992) Prevention of the first occurrence of neural-tube defects by periconceptional vitamin supplementation. New England Journal of Medicine 327, 1832-1835.

Davie EW \& Ratnoff OD (1964) Waterfall sequence for intrinsic blood clotting. Science 145, 1310-1312.

Dekker GA, de Vries JIP, Doelitzsch PM, Huijgens PC, von Blomberg BME, Jakobs C \& van Geijn HP (1995) Underlying disorders associated with severe early-onset pre-eclampsia. American Journal of Obstetrics and Gynecology 173, 1042-1048.

D'Elia AV, Driul L, Giacomello R, Colaone R, Fabbro D, Di Leonardo C, Florio P, Petraglia F, Marchesoni D \& Damante G (2002) Frequency of factor V, prothrombin and methylenetetrahydrofolate reductase in pre-eclampsia. Gynecologic and Obstetric Investigation 53, 84-87.

de Jong SC, Stehouwer CD, van den Berg M, Vischer UM, Rauwerda JA \& Emeis JJ (1997) Endothelial marker proteins in hyperhomocysteinemia. Thrombosis and Haemostasis 78, 1332-1337.

de Moerloose P, Amiral J, Vissac AM \& Reber G (1998a) Longitudinal study on activated factors XII and VII levels during normal pregnancy. British Journal of Haematology 100, $40-44$.

de Moerloose P, Mermillod N, Amiral J \& Reber G (1998b) Thrombomodulin levels during normal pregnancy, at delivery and in the postpartum: comparison with tissue-type plasminogen activator and plasminogen activator inhibitor-1. Thrombosis and Haemostasis 79, 554-556.

den Heijer M, Koster T, Blom HJ, Bos GMJ, Briët E, Reitsma PH, Vandenbroucke JP \& Rosendaal FR (1996) Hyperhomocysteinemia as a risk factor for deep-vein thrombosis. New England Journal of Medicine 334, 759-762. 
Department of Health (1992) Report from an Expert Advisory Group. Folic Acid and the Prevention of Neural Tube Defects. London: Department of Health.

de Valk-de Roo GW, Stehouwer CD, Lambert J, Schalkwijk CG, van der Mooren MJ, Kluft C \& Netelenbos C (1999) Plasma homocysteine is weakly correlated with plasma endothelin and von Willebrand factor but not with endothelium-dependent vasodilatation in healthy postmenopausal women. Clinical Chemistry 45, 1200-1205.

de Vries JIP, Dekker GA, Huijgens PC, Jakobs C, Blomberg BME \& van Geijn HP (1997) Hyperhomocysteinaemia and protein S deficiency in complicated pregnancies. British Journal of Obstetrics and Gynaecology 104, 1248-1254.

Dimitrova KR, DeGroot K, Myers AK \& Kim YD (2002) Estrogen and homocysteine. Cardiovascular Research 53, 577-588.

Donohoe S, Quenby S, Mackie I, Panal G, Farquharson R, Malia R, Kingdom J \& Machin S (2002) Fluctuations in levels of antiphospholipid antibodies and increased coagulation activation markers in normal and heparin-treated antiphospholipid syndrome pregnancies. Lupus 11, 11-20.

Douglas JT, Shah M, Lowe GDO, Belch JJF, Forbes CD \& Prentice CRM (1982) Plasma fibrinopeptide A and beta-thromboglobulin in pre-eclampsia and pregnancy hypertension. Thrombosis and Haemostasis 47, 54-55.

Drake TA, Morrissey JH \& Edgington TS (1989) Selective cellular expression of tissue factor in human tissues. Implications for disorders of hemostasis and thrombosis. American Journal of Pathology 134, 1087-1097.

Durand P, Lussier-Cacan S \& Blache D (1997) Acute methionine load-induced hyperhomocysteinemia enhances platelet aggregation, thromboxane biosynthesis, and macrophage-derived tissue factor activity in rats. FASEB Journal 11, 1157-1168.

Eichinger S, Stümpflen A, Hirschl M, Bialonczyk C, Herkner K, Stain M, Schneider B, Pabinger I, Lechner K \& Kyrle PA (1998) Hyperhomocysteinemia is a risk factor of recurrent venous thromboembolism. Thrombosis and Haemostasis 80, 566-569.

Eichinger S, Welttermann A, Phillip K, Hafner E, Kaider A, Kittl E, Brenner B, Mannhalter C, Lechner K \& Kyrle PA (1999) Prospective evaluation of hemostatic system activation and thrombin potential in healthy pregnant women with and without factor V Leiden. Thrombosis and Haemostasis 82, 1232-1236.

Estelles A, Gilabert J, Anznar J, Loskutoff DJ \& Schleef RR (1989) Changes in the plasma levels of type 1 and type 2 plasminogen activator inhibitors in normal pregnancy and in patients with severe pre-eclampsia. Blood 74, 1332-1338.

Falcon CR, Cattaneo M, Panzeri D, Martinelli I \& Mannucci PM (1994) High prevalence of hyperhomocyst(e)inemia in patients with juvenile venous thrombosis. Arteriosclerosis and Thrombosis 14, 1080-1083.

Faught W, Garner P, Jones G \& Ivey B (1995) Changes in protein $\mathrm{C}$ and protein $\mathrm{S}$ levels in normal pregnancy. American Journal of Obstetrics and Gynecology 172, 147-150.

Fernandez JA, Estelles A, Gilabert J, Espana F \& Aznar J (1989) Functional and immunologic protein $\mathrm{S}$ in normal pregnant women and in full-term newborns. Thrombosis and Haemostasis 61, 474-478.

Finkelstein JD (2000) Pathways and regulation of homocysteine metabolism in mammals. Seminars in Thrombosis and Haemostasis 26, 219-225.

Foka ZJ, Lambropoulos AF, Saravelos H, Karas GB, Karavida A, Agorastos T, Zournatzi V, Makris PE, Bontis J \& Kotsis A (2000) Factor V Leiden and prothrombin G20210A mutations, but not methylenetetrahydrofolate reductase $\mathrm{C} 677 \mathrm{~T}$, are associated with recurrent miscarriage. Human Reproduction 15, 458-462.

Folsom AR, Nieto FJ, McGovern PG, Tsai MY, Malinow MR, Eckfeldt JH, Hess DL \& Davis CE (1998) Prospective study of coronary heart disease incidence in relation to fasting total homocysteine, related genetic polymorphisms, and B vitamins The Atherosclerosis Risk in Communities (ARIC) study. Circulation 98, 204-210.

Francalanci I, Comeglio P, Liotta AA, Cellai AP, Fedi S, Parretti E, Mello G, Prisco D \& Abbate R (1995) D-dimer concentrations during normal pregnancy, as measured by ELISA. Thrombosis Research 78, 399-405.

Freyburger G, Labrouche S, Sassoust G, Rouanet F, Javorschi S \& Parrot F (1997) Mild hyperhomocysteinemia and hemostatic factors in patients with arterial vascular diseases. Thrombosis and Haemostasis 77, 466-471.

Frosst P, Blom HJ, Milos R, Goyette P, Sheppard CA, Matthews RG, Boers GJH, den Heijer M, Kluijtmans LAJ, van den Heuvel LP \& Rozen R (1995) A candidate genetic risk factor for vascular disease: a common mutation in methylenetetrahydrofolate reductase. Nature Genetics 10, 111-113.

Fryer RH, Wilson BD, Gubler DB, Fitzgerald LA \& Rodgers GM (1993) Homocysteine, a risk factor for premature vascular disease and thrombosis, induces tissue factor activity in endothelial cells. Arteriosclerosis and Thrombosis 13, 1327-1333.

Gatti L, Tenconi PM, Guarneri D, Bertulessi C, Ossola MW, Bosco P \& Gianotti GA (1994) Hemostatic parameters and platelet activation by flow-cytometry in normal pregnancy: a longitudinal study. International Journal of Clinical and Laboratory Research 24, 217-219.

Gemmati D, Previati M, Serino ML, Moratelli S, Guerra S, Capitani S, Forini E, Ballerini G \& Scapoli GL (1999a) Low folate levels and thermolabile methylenetetrahydrofolate reductase as primary determinant of mild hyperhomocysteinemia in normal and thromboembolic subjects. Arteriosclerosis, Thrombosis and Vascular Biology 19, 1761-1767.

Gemmati D, Serino ML, Trivellato C, Fiorini S \& Scapoli GL (1999b) C677T substitution in the methylenetetrahydrofolate reductase gene as a risk factor for venous thrombosis and arterial disease in selected patients. Haematologica 84, 824-828.

George JN (2000) Platelets. Lancet 355, 1531-1539.

Gerbasi FR, Bottoms S, Farag A \& Mammem E (1990) Increased intravascular coagulation associated with pregnancy. Obstetrics and Gynecology 75, 385-389.

Gharavi AE, Pierangeli SS, Levy RA \& Harris EN (2001) Mechanism of pregnancy loss in antiphospholipid syndrome. Clinical Obstetrics and Gynecology 44, 11-19.

Gherman RB, Goodwin TM, Leung B, Byrne JD, Hethumumi R \& Montoro M (1999) Incidence, clinical characteristics, and timing of objectively diagnosed venous thromboembolism during pregnancy. Obstetrics and Gynecology, 94, 730-734.

Goddijn-Wessel TAW, Wouters MGAJ, van der Molen EF, Spuijbroek MDEH, Steegers-Theunissen RPM, Blom HJ, Boers GHJ \& Eskes TKAB (1996) Hyperhomocysteinemia: a risk factor for placental abruption or infarction. European Journal of Obstetrics and Gynecology and Reproductive Biology 66, 23-29.

Grandone E, Margaglione M, Colaizzo D, Cappucci G, Paladini D, Martinelli P, Montanaro S, Pavone G \& Di Minno G (1997) Factor V Leiden, C $>$ T MTHFR polymorphism and genetic susceptibility to pre-eclampsia. Thrombosis and Haemostasis $\mathbf{7 7}$, 1052-1054.

Grandone E, Margaglione M, Colaizzo D, D’Andrea G, Cappucci G, Brancaccio V \& Di Minno G (1998) Genetic susceptibility to pregnancy-related venous thromboembolism: roles of factor $\mathrm{V}$ Leiden, prothrombin G20210A, and methylenetetrahydrofolate reductase C677T mutations. American Journal of Obstetrics and Gynecology 179, 1324-1328.

Greer IA (1994) Haemostasis and thrombosis in pregnancy. In Haemostasis and Thrombosis, 3rd ed., pp. 987-1015 [AL 
Bloom, CD Forbes, DP Thomas and EGD Tuddenham, editors]. Edinburgh: Churchill Livingstone.

Greer IA (1999) Thrombosis in pregnancy: maternal and fetal issues. Lancet 353, 1258-1265.

Greer IA (2001) Procoagulant microparticles: new insights and opportunities in pregnancy loss? Thrombosis and Haemostasis 85, 3-4.

Gris JC, Quere I, Monpeyroux F, Mercier E, Ripart-Neveu S, Tailland ML, Hoffet M, Berlan J, Daures JP \& Mares P (1999) Case-control study of the frequency of thrombophilic disorders in couples with late foetal loss and no thrombotic antecedent the Nimes Obstetricians and Haematologists study 5 (NOHA5). Thrombosis and Haemostasis 81, 891-899.

Hajjar KA (1993) Homocysteine-induced modulation of tissue plasminogen activator to its endothelial cell membrane receptor. Journal of Clinical Investigation 91, 2873-2879.

Hajjar KA \& Jacovina AT (1998) Modulation of anexin II by homocysteine: implications for atherothrombosis. Journal of Investigative Medicine 46, 364-369.

Hayashi T, Honda G \& Suzuki K (1992) An atherogenic stimulus homocysteine inhibits cofactor activity of thrombomodulin and enhances thrombomodulin expression in human umbilical vein endothelial cells. Blood 79, 2930-2936.

Hellgren M \& Blombäck M (1981) Studies on blood coagulation and fibrinolysis in pregnancy, during delivery and in the puerperium. Gynecologic and Obstetric Investigation 12, 141-154.

Hemker HC \& Beguin S (1995) Thrombin generation in plasma: its assessment via the endogenous thrombin potential. Thrombosis and Haemostasis 74, 134-138.

Hofmann MA, Kohl B, Zumbach MS, Borcea V, Bierhaus A, Henkels M, Admiral J, Schmidt AM, Fiehn W, Ziegler R, Wahl P \& Nawroth PP (1998) Hyperhomocyst(e)inemia and endothelial dysfunction in IDDM. Diabetes Care 21, 841-848.

Holmes VA, Wallace JMW, Gilmore WS, McFaul P \& Alexander HD (2002) Tissue factor expression on monocyte subpopulations during normal pregnancy. Thrombosis and Haemostasis 87, 953-958.

Homocysteine Lowering Trialists' Collaboration (1998) Lowering blood homocysteine with folic acid based supplements: metaanalysis of randomised trials. British Medical Journal 316, 894-898.

Hutton RA, Laffan MA \& Tuddenham EGD (1999) Normal haemostasis. In Postgraduate Haematology, 4th ed., pp. 550-580 [AV Hoffbrand, SM Lewis and EDG Tuddenham, editors]. Oxford: Butterworth Heinemann.

Kaiser T, Brennecke SP \& Moses EK (2001) C677T methylenetetrahydrofolate reductase polymorphism is not a risk factor for pre-eclampsia/eclampsia among Australian women. Human Heredity 51, 20-22.

Kang SS, Wong PWK \& Norusis M (1987) Homocysteinemia due to folate deficiency. Metabolism 36, 458-462.

Kang SS, Wong PWK, Zhou J \& Cook HY (1986) Total homocyst(e)ine in plasma and amniotic fluid of pregnant women. Metabolism 35, 889-891.

Kario K, Duell PB, Matsuo T, Sakata T, Kato H, Shimada K \& Miyata T (2001) High plasma homocyst(e)ine levels in elderly Japanese patients are associated with increased cardiovascular disease risk independently from markers of coagulation activation and endothelial cell damage. Atherosclerosis 157, 441-449.

Khajuria A \& Houston DS (2000) Induction of monocyte tissue factor expression by homocysteine: a possible mechanism for thrombosis. Blood 96, 966-972.

Kjellberg U, Andersson NE, Rosén S, Tengborn L \& Hellgren M (1999) APC resistance and other haemostatic variables during pregnancy and puerperium. Thrombosis and Haemostasis 81, $527-531$.
Kluijtmans LAJ, den Heijer M, Reitsma PH, Heil SG, Blom HJ \& Rosendaal FR (1998) Thermolabile methylenetetrahydrofolate reductase and factor $\mathrm{V}$ Leiden in the risk of deep-vein thrombosis. Thrombosis and Haemostasis 79, 254-258.

Kristensen B, Malm J, Nilsson TK, Hultdin J, Carlberg B, Dahlén G \& Olsson T (1999) Hyperhomocysteinemia and hypofibrinolysis in young adults with ischemic stroke. Stroke 30, 974-980.

Kuch B, Bobak M, Fobker M, Junker R, von Eckardstein A, Marmot M \& Hense HW (2001) Associations between homocysteine and coagulation factors - a cross-sectional study in two populations of Central Europe. Thrombosis Research 103, 265-273.

Kunz K, Petitjean P, Lisri M, Chantrel F, Koehl C, Wiesel ML, Cazenave JP, Moulin B \& Hannedouche TP (1999) Cardiovascular morbidity and endothelial dysfunction in chronic haemodialysis patients: is homocyst(e)ine the missing link? Nephrology Dialysis Transplantation 14, 1934-1942.

Kupferminc MJ, Eldor A, Steinman N, Many A, Bar-Am A, Jaffa A, Fait G \& Lessing JB (1999) Increased frequency of genetic thrombophilia in women with complications of pregnancy. New England Journal of Medicine 340, 9-13.

Laude I, Rongières-Bertrand C, Boyer-Neumann C, Wolf M, Mairovitz V, Hugel B, Freyssinet JM, Frydman R, Meyler D \& Eschwège V (2001) Circulating procoagulant microparticles in women with unexplained pregnancy loss: a new insight. Thrombosis and Haemostasis 85, 18-21.

Lentz SR \& Sadler JE (1991) Inhibition of thrombomodulin surface expression and protein $\mathrm{C}$ activation by the thrombogenic agent homocysteine. Journal of Clinical Investigation $\mathbf{8 8}$, 1906-1914.

Lentz SR, Sobey CG, Piegors DJ, Bhopatkar MY, Faraci FM, Malinow MR \& Heistad DD (1996) Vascular dysfunction in monkeys with diet-induced hyperhomocyst(e)inemia. Journal of Clinical Investigation 98, 24-29.

Lindgren A, Lindoff C, Norrving B, Astedt B \& Johansson BB (1996) Tissue plasminogen activator and plasminogen activator inhibitor-1 in stroke patients. Stroke 27, 1066-1071.

Lindqvist P, Dahlbäck B \& Maršál K (1999) Thrombotic risk during pregnancy: a population study. Obstetrics and Gynecology 94, 595-599.

Ling Q \& Hajjar KA (2000) Inhibition of endothelial cell thromboresistance by homocysteine. Journal of Nutrition 130, 373S-376S.

Lyall F \& Greer IA (1996) The vascular endothelium in normal pregnancy and pre-eclampsia. Reviews of Reproduction 1, 107116.

McColl MD, Ellison J, Reid F, Tait RC, Walker ID \& Greer IA (2000) Prothrombin $20210 \mathrm{G} \rightarrow$ A, MTHFR C677T mutations in women with venous thromboembolism associated with pregnancy. British Journal of Obstetrics and Gynaecology 107, $565-569$.

McColl MD, Ramsay JE, Tait RC, Walker ID, McCall F, Conkie JA, Carty MJ \& Greer IA (1997) Risk factors for pregnancy associated venous thromboembolism. Thrombosis and Haemostasis 78, 1183-1188.

McColl MD, Walker ID \& Greer IA (1999) The role of inherited thrombophilia in venous thromboembolism associated with pregnancy. British Journal of Obstetrics and Gynaecology 106, 756-766.

McKinley MC, McNulty H, McPartlin J, Strain JJ, Pentieva K, Ward M, Weir DG \& Scott JM (2001) Low dose vitamin B-6 effectively lowers fasting homocysteine in healthy elderly persons who are folate and riboflavin replete. American Journal of Clinical Nutrition 73, 759-764.

McPartlin J, Halligan A, Scott JM, Darling M \& Weir DG (1993) Accelerated folate breakdown in pregnancy. Lancet 341, 148-149. 
Macfarlane RG (1964) An enzyme cascade in the blood clotting mechanism, and its function as a biochemical amplifier. Nature 202, 498-499.

Macklon NS \& Greer IA (1996) Venous thromboembolic disease in obstetrics and gynaecology: the Scottish experience. Scottish Medical Journal 41, 83-86.

Macklon NS, Greer IA \& Bowman AW (1997) An ultrasound study of gestational and postural changes in the deep venous system of the leg in pregnancy. British Journal of Obstetrics and Gynaecology 104, 191-197.

Malinow MR, Rajkovic A, Duell PB, Hess DL \& Upson BM (1998) The relationship between maternal and neonatal umbilical cord plasma homocyst(e)ine suggests a potential role for maternal homocyst(e)ine in fetal metabolism. American Journal of Obstetrics and Gynecology 178, 228-233.

Malm J, Laurell M \& Dahlback B (1988) Changes in the plasma levels of vitamin K-dependent proteins $\mathrm{C}$ and $\mathrm{S}$ and of $\mathrm{C} 4 \mathrm{~b}-$ binding protein during pregnancy and oral contraception. British Journal of Haematology 68, 437-443.

Many A, Schreiber L, Rosner S, Lessing JB, Eldor A \& Kupferminc MJ (2001) Pathologic features of the placenta in women with severe pregnancy complications and thrombophilia. Obstetrics and Gynecology 98, 1041-1044.

Marcucci R, Fedi S, Brunelli T, Pepe G, Prisco D, Rosait A, Zanazzi M, Bertoni E, Abbate R \& Salvadori M (2001) High cysteine levels in renal transplant recipients: relationship with hyperhomocysteinemia and 5,10-MTHFR polymorphism. Transplantation 27, 746-751.

Marcucci R, Prisco D, Brunelli T, Pepe G, Gori AM, Fedi S, Capanni M, Simotetti I, Federici G, Pastore A, Abbate R \& Gensini GF (2000) Tissue factor and homocysteine levels in ischemic heart disease are associated with angiographically documented clinical recurrences after coronary angioplasty. Thrombosis and Haemostasis 83, 826-832.

Massouh M, Jatoi A, Gordon EM \& Ratnoff OD (1989) Heparin cofactor II activity in plasma during pregnancy and oral contraceptive use. Journal of Laboratory and Clinical Medicine 114, 697-699.

Mathonnet F, de Mazancourt P, Bastenaire B, Morot M, Benattar N, Beufe S, Borg JY \& Giudicelli Y (1996) Activated protein C sensitivity ratio in pregnant women at delivery. British Journal of Haematology 92, 224-246.

Mayer O, Filipsvský J, Hromádka M, Svobodová V, Racek J, Mayer O Jr, Stehlík P, Trefil L \& Zárybnická M (2002) Treatment of hyperhomocysteinemia with folic acid: effects on homocysteine levels, coagulation status, and oxidative stress markers. Journal of Cardiovascular Pharmacology 39, 851-857.

Mayer O Jr, Šimon J, Rosolová H, Hromádka M, Šubrt I \& Vobrubová I (2002) The effects of folate supplementation on some coagulation parameters and oxidative status surrogates. European Journal of Clinical Pharmacology 58, 1-5.

Medical Research Council Vitamin Study Research Group (1991) Prevention of neural tube defects: Results of the Medical Research Council Vitamin Study. Lancet 338, 131-137.

Midorikawa S, Sanada H, Hashimoto S \& Watanabe T (2000) Enhancement by homocysteine of plasminogen activator inhibitor-1 gene expression and secretion from vascular endothelial and smooth muscle cells. Biochemical and Biophysical Research Communications 272, 182-185.

Mijatovic V, Kenemans P, Jakobs C, van Baal WM, Peters-Muller ER \& van der Mooren MJ (1998a) A randomized controlled study of the effects of 17beta-estradiol-dydrogesterone on plasma homocysteine in postmenopausal women. Obstetrics and Gynecology 91, 432-436.

Mijatovic V, Netelenbos C, van der Mooren MJ, de Valk-de Roo GW, Jakobs C \& Kenemans P (1998b) Randomized, doubleblind, placebo controlled study of the effects of raloxifene and conjugated equine estrogen on plasma homocysteine levels in healthy postmenopausal women. Fertility and Sterility $\mathbf{7 0}$, $1085-1089$.

Mills JL, McPartlin JM, Kirke PN, Lee YJ, Conley MR, Weir DG \& Scott JM (1995) Homocysteine metabolism in pregnancies complicated by neural-tube defects. Lancet 345, 149-151.

Morawitz P (1905) Die Chemie der Blutgerinnung (The chemistry of blood clotting). Ergebnisse der Physiologie 4, 307-422.

Morris MS, Jacques PF, Selhub J \& Rosenberg IH (2000) Total homocysteine and estrogen status indicators in the Third National Health and Nutrition Examination Survey. American Journal of Epidemiology 152, 140-148.

Mousa HA \& Alfirevicl Z (2000) Do placental lesions reflect thrombophilia state in women with adverse pregnancy outcome? Human Reproduction 15, 1830-1833.

Mudd SH, Skovby F, Levy HL, Pettigrew KD, Wilcken B, Pyeritz RE, Andria G, Boers GH, Bromberg IL, Cerone R, Fowler B, Gröbe H, Schimdt H \& Schweitzer L (1985) The natural history of homocystinuria due to cystathionine $\beta$-synthase deficiency. American Journal of Human Genetics 37, 1-31.

Naruszewicz M, Klinke M, Dziewanowski K, Staniewicz A \& Bukowska H (2001) Homocysteine, fibrinogen, and lipoprotein (a) levels are simultaneously reduced in patients with chromic renal failure treated with folic acid, pyridoxine, and cyanocobalamin. Metabolism 50, 131-134.

Nelan WLDM, Blom HJ, Steegers EAP, den Heijer M, Thomas CMG \& Eskes TKAB (2000) Homocysteine and folate levels as risk factors for recurrent early pregnancy loss. Obstetrics and Gynecology 95, 519-524.

Nemerson Y (1988) Tissue factor and hemostasis. Blood 71, 1-8.

Neuman F, Ott I, Marx N, Luther T, Kenngott S, Gawaz M, Kotzch M \& Schomig A (1997) Effect of human recombinant interleukin-6 and interleukin-8 on monocyte procoagulant activity. Arteriosclerosis, Thrombosis and Vascular Biology 17, 3399-3405.

Nishinaga M, Ozawa T \& Shimada K (1993) Homocysteine, a thrombogenic agent, suppresses anticoagulant heparan sulfate expression in cultured porcine aortic endothelial cells. Journal of Clinical Investigation 92, 1381-1386.

Nygård O, Refsum H, Ueland PM, Stensvold I, Nordrehaug JE, Kvale G \& Vollset SE (1997) Coffee consumption and plasma total homocysteine: the Hordaland Homocysteine Study. American Journal of Clinical Nutrition 65, 136-143.

Nygård O, Refsum H, Ueland PM \& Vollset SE (1998) Major lifestyle determinants of plasma total homocysteine distribution: the Hordaland Homocysteine Study. American Journal of Clinical Nutrition 67, 263-270.

Nygård $\mathrm{O}$, Vollset SE, Refsum $\mathrm{H}$, Stensvold I, Tverdal A, Nordrehaug JE, Ueland PM \& Kvale G (1995) Total plasma homocysteine and cardiovascular risk profile: The Hordaland Homocysteine Study. Journal of the American Medical Association 274, 1526-1533.

Øian P, Omsjø I, Maltau JM \& Østerud B (1985) Reduced thromboplastin activity in blood monocytes and reduced sensitivity to stimuli in vitro of blood monocytes from pregnant women. British Journal of Haematology 59, 133-137.

Owen CA (2001) Modern concept of the scheme of blood coagulation. In A History of Blood Coagulation, 1st ed., pp. 111-113 [WL Nichols and EJW Bowie, editors]. Rochester, MN: Mayo Foundation.

Palareti G \& Coccheri S (1989) Lowered antithrombin III activity and other clotting changes in homocystinuria: effects of pyridoxine-folate regimen. Haemostasis 19, 24S-28S.

Peek MJ, Nelson-Piercy C, Manning RA, de Swiet M \& Letsky EA (1997) Activated protein C resistance in normal pregnancy. British Journal of Obstetrics and Gynaecology 104, 1084-1086. 
Persson BL, Stenberg P, Holmberg L \& Astedt B (1980) Transamidating enzymes in maternal plasma and placenta in human pregnancies complicated by intrauterine growth retardation. Journal of Development Physiology 2, 37-46.

Powers RW, Evans RW, Majors AK, Ojimba JI, Ness RB, Crombleholme WR \& Roberts JM (1998) Plasma homocysteine concentration is increased in pre-eclampsia and is associated with evidence of endothelial activation. American Journal of Obstetrics and Gynecology 179, 1605-1611.

Powers RW, Minich LA, Lykins DL, Ness RB, Crombleholme WR \& Roberts JM (1999) Methylenetetrahydrofolate reductase polymorphism, folate, and susceptibility to pre-eclampsia. Journal of the Society for Gynecologic Investigation 6, 74-79.

Preston FE, Rosendaal FR, Walker ID, Briët D, Brentorp E, Conrad J, Fontcuberta J, Makris M, Mariani G, Noteboom W, Pabinger I, Legnani C, Scharrer I, Schulman S \& van der Meer FJM (1996) Increased fetal loss in women with heritable thrombophilia. Lancet 348, 913-916.

Public Health Services, Centre for Disease Control and Prevention (1992) Recommendations for the use of folic acid to reduce the number of cases of spina bifida and other neural tube defects. Morbidity and Mortality Weekly Report 41, 1-7.

Quèrè I, Bellart H, Hoffet M, Janbon C, Mares P \& Gris J (1998) A woman with five consecutive fetal deaths: case report and retrospective analysis of hyperhomocysteinemia prevalence in 100 consecutive women with recurrent miscarriages. Fertility and Sterility 69, 152-154.

Quinlivan EP, McPartlin J, McNulty H, Ward M, Strain JJ, Weir DG \& Scott JM (2002) Importance of both folic acid and vitamin B12 in reduction of risk of vascular disease. Lancet 359 , 227-228.

Quinlivan EP, McPartlin J, Weir DG \& Scott JM (2000) Decreased serum homocysteine in pregnancy: possible role in methylation cycle regulation. Proceedings of the Nutrition Society 59, 96A.

Rai R, Cohen H, Dave M \& Regan L (1997) Randomised controlled trial of aspirin and aspirin plus heparin in pregnant women with recurrent miscarriage associated with phospholipid antibodies (or antiphospolipid antibodies). British Medial Journal 314, 253-257.

Rajkovic A, Catalano PM \& Malinow MR (1997) Elevated homocyst(e)ine levels with pre-eclampsia. Obstetrics and Gynecology 90, 168-171.

Rapaport SI \& Rao VM (1995) The tissue factor pathway: how it has become a 'prima ballerina'. Thrombosis and Haemostasis 74, 7-17.

Ray JG, Langman LJ, Vermeulen MJ, Evrovski J, Yeo EL \& Cole DEC (2001) Genetics University of Toronto Thrombophilia Study in Women (GUTTSI): genetic and other risk factor for venous thromboembolism in women. Current Controlled Trials in Cardiovascular Medicine 2, 141-149.

Ray JG \& Laskin CA (1999) Folic acid and homocyst(e)ine metabolic defects and the risk of placental abruption, pre-eclampsia and spontaneous pregnancy loss: A systematic review. Placenta 20, 519-529.

Reber G, Amiral J \& de Moerloose P (1998) Modified antithrombin III levels during normal pregnancy and relationship with prothrombin fragment $\mathrm{F} 1+2$ and thrombin-antithrombin complexes. Thrombosis Research 91, 45-47.

Refsum H, Helland S \& Ueland PM (1985) Radioenzymic determination of homocysteine in plasma and urine. Clinical Chemistry 31, 624-628.

Rodgers GM \& Conn MT (1990) Homocysteine, an atherogenic stimulus, reduces protein $\mathrm{C}$ activation by arterial and venous endothelial cells. Blood 75, 895-901.

Rodgers GM \& Kane WH (1986) Activation of endogenous factor $\mathrm{V}$ by a homocysteine-induced vascular endothelial cell activator. Journal of Clinical Investigation 77, 1909-1916.
Rolschau J, Date J \& Kristoffersen K (1979) Folic acid supplement and intrauterine growth. Acta Obstetrica and Gynecologica Scandinavica 58, 343-346.

Rolschau J, Kristoffersen K, Ulrich M, Grinsted P, Schaumburg E \& Foged N (1999) The influence of folic acid supplement on the outcome of pregnancies in the county of Funen in Denmark. Part I. European Journal of Obstetrics and Gynecology and Reproductive Biology 87, 105-110.

Rosendaal FR (1999) Venous thrombosis: a multicausal disease. Lancet 353, 1167-1173.

Salomon O, Steinberg DM, Zivelin A, Gitel S, Dardik R, Rosenberg N, Berliner S, Inbal A, Many A, Lubetsky A, Varon D, Martinowitz U \& Seligsohn U (1999) Single and combined prothrombotic factors in patients with idiopathic venous thromboembolism: prevalence and risk assessment. Arteriosclerosis, Thrombosis and Vascular Biology 19, 511-518.

Schlit A, Col-de Beys C, Moriau M \& Lavenne-Pardonge E (1996) Acquired activated protein $\mathrm{C}$ resistance in pregnancy. Thrombosis Research 84, 203-206.

Schwagner I \& Jungi TW (1994) Effect of human recombinant cytokines on the induction of macrophage procoagulant activity. Blood 83, 152-160.

Selhub J, Jacques PF, Wilson PWF, Rush D \& Rosenbery IH (1993) Vitamin status and intake as primary determinants of homocysteinemia in an elderly population. Journal of the American Medical Association 270, 2693-2698.

Sheppard BL \& Bonnar J (1999) Uteroplacental hemostasis in intrauterine fetal growth retardation. Seminars in Thrombosis and Hemostasis 25, 443-446.

Shu H, Wramsby M, Bokarewa M, Blombäck M \& Bremme K (2000) Decrease in protein $C$ inhibitor activity and acquired APC resistance during normal pregnancy. Journal of Thrombosis and Thrombolysis 9, 277-281.

Sikkema JM, Franx A, Bruinse HW, van der Wijk NJ, de Valk HW \& Nikkels PG (2002) Placental pathology in early onset preeclampsia and intra-uterine growth restriction in women with and without thrombophilia. Placenta 23, 337-342.

Simpson EL, Lawrenson RA, Nightingale AL \& Farmer RDT (2001) Venous thromboembolism in pregnancy and the puerperium: incidence and additional risk factors from a London perinatal database. British Journal of Obstetrics and Gynaecology 108, 56-60.

Somekawa Y, Kobayashi K, Tomura S, Aso T \& Hamaguchi H (2002) Effects of hormone replacement therapy and methylenetetrahydrofolate reductase polymorphism on plasma folate and homocysteine levels in postmenopausal Japanese women. Fertility and Sterility 77, 481-486.

Steegers-Theunissen RPM, Boers GHJ, Trijbels FJM, Finkelstein JD, Blom HJ, Thomas CMG, Borm GF, Wouters MGAJ \& Eskes TKAB (1994) Maternal hyperhomocysteinemia: a risk factor for neural-tube defects? Metabolism 43, 1475-1480.

Stirling Y, Woolf L, North WRS, Seghatchian MJ \& Meade TW (1984) Haemostasis in normal pregnancy. Thrombosis and Haemostasis 52, 176-182.

Thambyrajah J, Landray MJ, Jones HJ, McGlynn FJ, Wheeler DC \& Townend JN (2001) A randomized double-blind placebocontrolled trial of the effect of homocysteine-lowering therapy with folic acid on endothelial function in patients with coronary artery disease. Journal of the American College of Cardiology 37, 1858-1863.

Thambyrajah J, Landray MJ, McGlynn FJ, Jones HJ, Wheeler DC \& Townend JN (2000) Does folic acid decrease plasma homocysteine and improve endothelial function in patients with predialysis renal failure? Circulation 102, 871-875.

Ubbink JB, Becker PJ, Veramaak WJH \& Delport R (1995) Results of B-vitamin supplementation study used in a prediction model 
to define a reference range for plasma homocysteine. Clinical Chemistry 41, 1033-1037.

Ubbink JB, Vermaak WJH, van der Merwe A, Becker PJ, Delport R \& Potgieter HC (1994) Vitamin requirements for the treatment of hyperhomocysteinemia in humans. Journal of Nutrition 124, 1927-1933.

Ueland PM, Refsum H, Stabler SP, Malinow MR, Andersson A \& Allen RH (1993) Total homocysteine in plasma or serum: methods and clinical applications. Clinical Chemistry 39, 1764-1779.

Undas A, Domagala TB, Jankowski M \& Szczeklik A (1999) Treatment of hyperhomocysteinemia with folic acid and vitamins $\mathrm{B}_{12}$ and $\mathrm{B}_{6}$ attenuates thrombin generation. Thrombosis Research 95, 281-288.

Undas A, Williams EB, Butenas S, Orfeo T \& Mann K (2001) Homocysteine inhibits inactivation of factor $\mathrm{Va}$ by activated protein C. Journal of Biological Chemistry 276, 4389-4397.

Uszynski M, Zekanowska E, Uszynski W \& Kuczynski J (2001) Tissue factor (TF) and tissue factor pathway inhibitor (TFPI) in amniotic fluid and blood plasma: implications for the mechanism of amniotic fluid embolism. European Journal of Obstetrics and Gynecology and Reproductive Biology 95, 163-166.

van Baal WM, Smolders RGV, van der Mooren MJ, Teerlink T \& Kenemans P (1999) Hormone replacement therapy and plasma homocysteine levels. Obstetrics and Gynecology 94, 485-491.

van den Berg M, Boers GH, Franken DG, Blom HJ, van Kamp GJ, Jakobs C, Rauwerda JA, Kluft C \& Stehouwert CD (1995) Hyperhomocysteinemia and endothelial dysfunction in young patients with peripheral arterial occlusive disease. European Journal of Clinical Investigation 25, 176-181.

van der Gaag MS, Ubbink JB, Sillanaukee P, Nikkari S \& Hendriks HF (2000) Effects of consumption of red wine, spirits, and beer on serum homocysteine. Lancet 355, 1522.

van der Molen EF, Verbruggen B, Nováková I, Eskes TKAB, Monnens LAH \& Blom HJ (2000) Hyperhomocysteinemia and other thrombotic risk factors in women with placental vasculopathy. British Journal of Obstetrics and Gynaecology 107, 785-791.

van Hinsbergh VWM (2001) The endothelium: vascular control of haemostasis. European Journal of Obstetrics and Gynaecology and Reproductive Biology 95, 198-201.

van Wersch JWJ \& Ubachs JMH (1991) Blood coagulation and fibrinolysis during normal pregnancy. European Journal of Clinical Chemistry and Clinical Biochemistry 29, 45-50.

van Wersch JWJ, Vooijs MEEC \& Ubachs JMH (1997) Coagulation factor XIII in pregnant smokers and non-smokers. International Journal of Clinical and Laboratory Research 27, 68-71.

Virchow R (1860) Cellular Pathology. London: Churchill.
Vollest SE, Refsum H, Irgens LM, Emblem BM, Tverkal A, Gjessing HK, Monsen ALB \& Ueland PM (2000) Plasma total homocysteine, pregnancy complications, and adverse pregnancy outcomes: the Hordaland Homocysteine Study. American Journal of Clinical Nutrition 71, 962-968.

von Eckardstein A, Malinow MR, Upson B, Heinrich J, Schulte H, Schonfeld R, Kohler E \& Assmann G (1994) Effects of age, lipoproteins, and hemostatic parameters on the role of homocyst(e)inemia as a cardiovascular risk factor in men. Arteriosclerosis and Thrombosis 14, 460-464.

Walker MC, Garner PR, Keely EJ, Rock GA \& Reis MD (1997) Changes in activated protein $\mathrm{C}$ resistance during normal pregnancy. American Journal of Obstetrics and Gynecology 177, $162-169$

Walker MC, Smith GN, Perkin SL, Keely EJ \& Garner PR (1999) Changes in homocysteine levels during normal pregnancy. Obstetrics and Gynecology 180, 660-664.

Ward M, McNulty H, McPartlin J, Strain JJ, Weir DG \& Scott JM (1997) Plasma homocysteine, a risk factor for cardiovascular disease, is lowered by physiological doses of folic acid. Quarterly Journal of Medicine 90, 519-524.

Whitaker AN, McFarlane JR, Rowe EA, Lee K \& Masci PP (1985) Measurement of autoantibodies against fibrinogen and fibrin degradation products by enzyme-linked immunoassay. Thrombosis and Haemostasis 53, 80-85.

Whitehead AS, Gallagher P, Mills JL, Kirke PN, Burke H, Molloy AM, Weir DG, Shields DC \& Scott JM (1995) A genetic defect in 5,10 methylenetetrahydrofolate reductase in neural tube defects. Quarterly Journal of Medicine 88, 763-766.

Wouters MGAJ, Boers GHJ, Blom HJ, Trijbels FJM, Thomas CMG, Borm GF, Steegers-Theunissen RPM \& Eskes TKAB (1993) Hyperhomocysteinemia: a risk factor in women with unexplained recurrent early pregnancy loss. Fertility and Sterility 60, 820-825.

Wright D, Poller L, Thomson JM, Sidebotham A, Hirst CF \& Hirsch P (1998) A longitudinal study of the factor VII rise during pregnancy. Thrombosis and Haemostasis 79, 328-330.

Wright JG, Cooper P, Astedt B, Lecander I, Wilde JT, Preston FE \& Greaves M (1988) Fibrinolysis during normal human pregnancy: complex inter-relationships between plasma levels of tissue plasminogen activator and inhibitors and the euglobulin clot lysis time. British Journal of Haematology $\mathbf{6 9}$, 253-258.

Yarnell JWG, Sweetnam PM, Rumley A \& Lowe GDO (2000) Lifestyle and hemostatic risk factors for ischemic heart disease - The Caerphilly Study. Arteriosclerosis, Thrombosis and Vascular Biology 20, 271-279. 